\title{
Will Restoration of Ecological Functions of Tank Cascade System Contribute to Reduce CKDu in Sri Lanka? A review
}

\author{
N. S. Abeysingha (Corresponding author) \\ Department of Agricultural Engineering and Soil Science, Faculty of Agriculture \\ Rajarata university of Sri Lanka, Puliyankulama, Anuradhapura, Sri Lanka \\ E-mail: nabeysingha@gmail.com
}

K. B. Dassanayake

Melbourne School of Engineering

The University of Melbourne, Victoria 3010, Australia

E-mail: kbd@unimelb.edu.au

\begin{abstract}
C. S. Weerarathna
Emeritus Professor of Soil and Water Resources, Faculty of Agriculture

Rajarata university of Sri Lanka, Puliyankulama, Anuradhapura, Sri Lanka

E-mail: csweera@sltnet.lk
\end{abstract}

Received: May 12, 2018 Accepted: June 8, 2018 Published: June 21, 2018

doi:10.5296/emsd.v7i3.13129 URL: https://doi.org/10.5296/emsd.v7i3.13129

\begin{abstract}
People in the dry zone of Sri Lanka where hydraulic civilization once thrived, suffer from occurrence of a chronic kidney disease of unknown etiology $(\mathrm{CKDu})$. The etiology for $\mathrm{CKDu}$ is now shown to be multi factorials and but related to water. Ancient people in the dry zone used surface water of tank cascades system and this system was interlinked with the ecosystem and social system of the area. It is hypothesized that the adverse changes that took place to the ecosystem of the tank cascade system and new commercial practices of agriculture in the CKDu prevalent area have also become reasons for the spreading of CKDu.
\end{abstract}


This review assesses the effect of different components of the tank cascade systems in improving the water quality. A number of studies have reported positive effects of improving the surface water quality of the tank by the Wew Ismaththa (closer catchment), Thaulla (upper peripheral gentle sloping land), Kattakaduwa (Interceptor) Iswetiya or Potawetiya (upstream soil ridges), Godawala (small silt trapping pond). The review also identified functions of Thaulla area approximately similar to a constructed wetland. This review highlights the issues and gaps in our understanding the ecological functioning of Globally Important Agricultural Heritage System. It is suggested that reconstruction of ecofriendly structural components of tanks and reestablishment of tank cascade system in the area would help to combat the spreading of CKDu in dry and intermediate zone of the country.

Keywords: Chronic kidney disease, Heavy metals, Tank cascade system, Ecology, Water Quality

\section{Introduction}

History of Sri Lanka is directly associated with the hydraulic civilization. Many civilizations such as Indus, Mexican, Maya and Inca had a long history and flourished with power and knowledge and faded away with passing the time. The causes behind the extinction cannot always be attributed to the attacks of other human nations and to the changes of the natural ecology, but it could be the consequence of the man made changes of the environment, outcome of the adverse agricultural environment etc. Sri Lankan hydraulic civilization has been an exception in this context though it had rise and falls during the past (Awsadahami, 2010). However, at present, an appreciable percentage of people in dry zone of Sri Lanka earlier Rajarata and Ruhunu rata where hydraulic civilization thrived suffer from the occurrence of chronic kidney disease of unknown etiology (CKDu). Due to its widespread geographical distribution and histopathological evidence, $\mathrm{CKDu}$ is considered a problem related to the environment. Hydro-geochemistry of the drinking water is believed to adversely effects the disease as it is highly endemic (Chandrajith et al., 2011). We observed that many hypotheses have been proposed as causative factors for CKDu and established at present as a multifactorial origin. However, these associated factors are related to water. We believe that this occurrence is due to the drastic changes happened to the hydraulic system of the dry and intermediate zone of the country. There is a growing concern over the high incidence of CKDu in dry and intermediate zone of Sri Lanka, and the ancient tank cascade system with its ecological functions has a potential for controlling this disease. Hence the present review was undertaken to find out the potential role of components of the tank cascade system in improving the water quality of the area and also the possibility of reestablishment of tank cascade system as aremedial measures for the spreading of this diseases in dry and intermediate zone in Sri Lanka.

\subsection{What is CKDu and its Spatial Distribution?}

Unlike Chronic Kidney Disease (CKD) which is considered to be caused by a number of factors such as diabetes, hypertension, and the various forms of glomerulonephritis. Chronic Kidney Disease $(\mathrm{CKDu})$ reported in some parts of Sri Lanka are not directly related to the above-mentioned factors and causal factors are not exactly known or well defined, hence, it is 


\section{Ml Macrothink}

referred to as CKD of uncertain origin. CKDu was first reported in the early 90s from North Central Province in Sri Lanka. Similar disease conditions are also recorded in India (e.g. Uddanam), Nicaragua, Costa Rica, Central American states, China, Serbia, Bulgaria, Romania, Croatia, and Bosnia (Gifford, 2017). In Sri Lanka, there are approximately 20,000 admissions/ re-admissions of patients with CKDu to government hospitals with around 2,000 deaths annually (http://www.presidentialtaskforce.gov.lk/en/kidney.html\#).
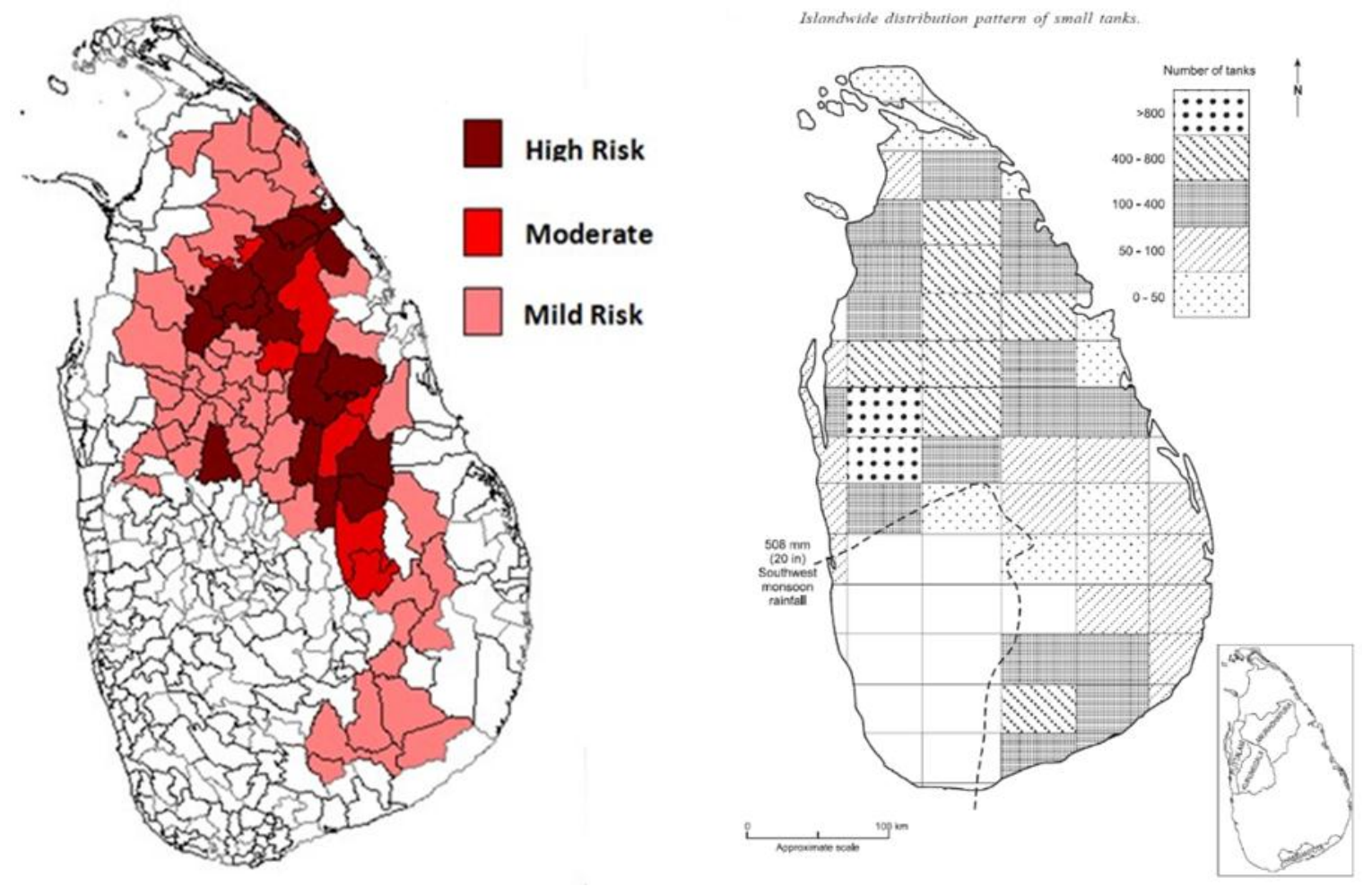

Figure 1. Registered CKDu patients upto December 2014 (adopted from http://www.presidentialtaskforce.gov.lk/en/kidn ey.html\#)

Figure 2. Island wide distribution of small tanks in Sri Lanka (adopted from Panabokke et al., 2002)

Figure 1 shows the divisional secretariat level distribution of CKDu patients in Sri Lanka while figure 2 exhibits the distribution of small tanks in Sri Lanka. We noted that the CKDu patient spatial distribution is approximately similar to those of tank spatial distribution. There are no reports indicating that the CKDu prevailed and significant death tall occurred during history in these regions. Instead, there are reports for the malaria infestation in recent past. That is also partially attributed to abundance of small tanks in the area. Therefore, we believe that the adverse changes that took place to the ecosystem of the tank cascade system or ellangawa (Sinhala folkloristic term) and new commercial practices of agriculture of dry and intermediate zone of the country have also become reasons for the spreading of CKDu. 


\subsection{Relationship of Causes of CKDu to Water}

Various studies exploring the etiology of CKDu suggested that heavy metals cadmium (Bandara et al., 2010; Jayathilake et al., 2013), arsenic (Jayasumana et al., 2013), elevated levels of fluoride in groundwater, the specific composition of groundwater (Chandrajith et al., 2011), aluminum (Illeperuma et al., 2009), weedicide (Jayasumana et al., 2014) and cyanobacterial toxins ( Dissanayake et al., 2011) excessive ground water iconicity ( Dharmawardena et al., 2015), excessive $\mathrm{PO}_{4}$ ions present in water (Dharma-wardana,2017) etc. as causative agents. However, no particular agent is conclusively established and this paper doesn't attempt to review the causative factors. Reviews of etiological factors for the CKDus are found in Rajapakse et al., 2016; Lunyera et al., 2015; Wanigasuriya 2012,2014; etc. We along with other authors Soderland et al., 2010; Wimalawansa 2014; Wanigasuriya 2012, etc. believed that $\mathrm{CKDu}$ is a multifactorial and environmentally acquired disease.

Jayasekara et al., 2013 showed that the communities who live closer to irrigation system obtaining well water sourced by natural springs are affected less than those communities using well water source by the seepage of irrigation water. Moreover, according to Dharma-wardena et al. (2015), prolonged use of excessively ionic water from fertilizer runoff through Mahaweli water diversion is considered to be a cause of CKDu by a Hofmeister-type protein denaturing mechanism in the kidney.

These findings clearly indicate that the use of groundwater and polluted surface water have been the cause for the occurrence of CKDu. Ancient Sinhalese community used surface water from small tanks as potable water, the use of groundwater was never practiced even for agriculture (Wijesekara, 2016). However, at present, the use of surface waters in the tank cascade system is questionable.

\section{What is Tank Cascade System?}

The dry zone, which covers the lowlands of the northern, north-central and eastern areas of the country, is subjected to several months of dry period extending from May to September. In order to overcome the limited water availability during this period, the ancient Sinhalese developed their own water management system now known as the Tank Cascade System. According to Madduma Bandara, 1985, "A 'tank cascade' is a connected series of tanks organized within a meso catchment of the dry zone landscape, storing, conveying and utilizing water from an ephemeral rivulet". However the Sinhala folkloristic term for this water management system is ellangava. This system has been recognized as a Globally Important Agricultural Heritage Systems" (GIAHS) by the FAO (FAO, 2018) as this system is adapted agricultural system managed with time tested indigenous techniques. As indicated in figure 3 , watershed boundary of the meso-catchment, the individual micro-catchment boundaries of the small tanks, the main central valley, side valleys, and axis of the main valley, component small tanks, and the irrigated rice lands (Sakthivadivel et al., 1997) are the main elements of a cascade. 


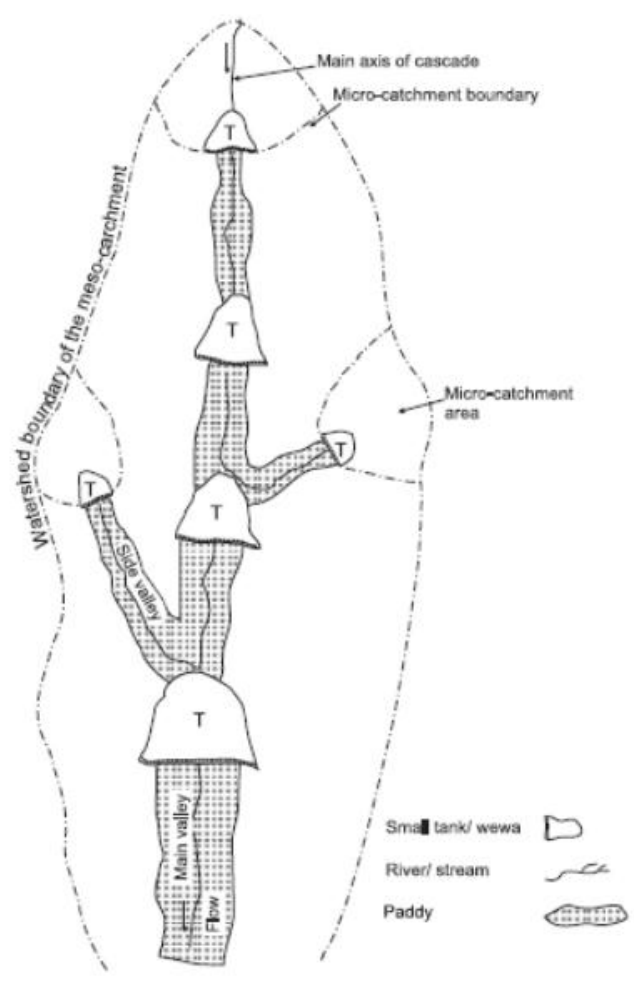

Figure 3. Schematic representation of small tank cascade system of Sri Lanka (adopted from Panabokke et al., 2002)

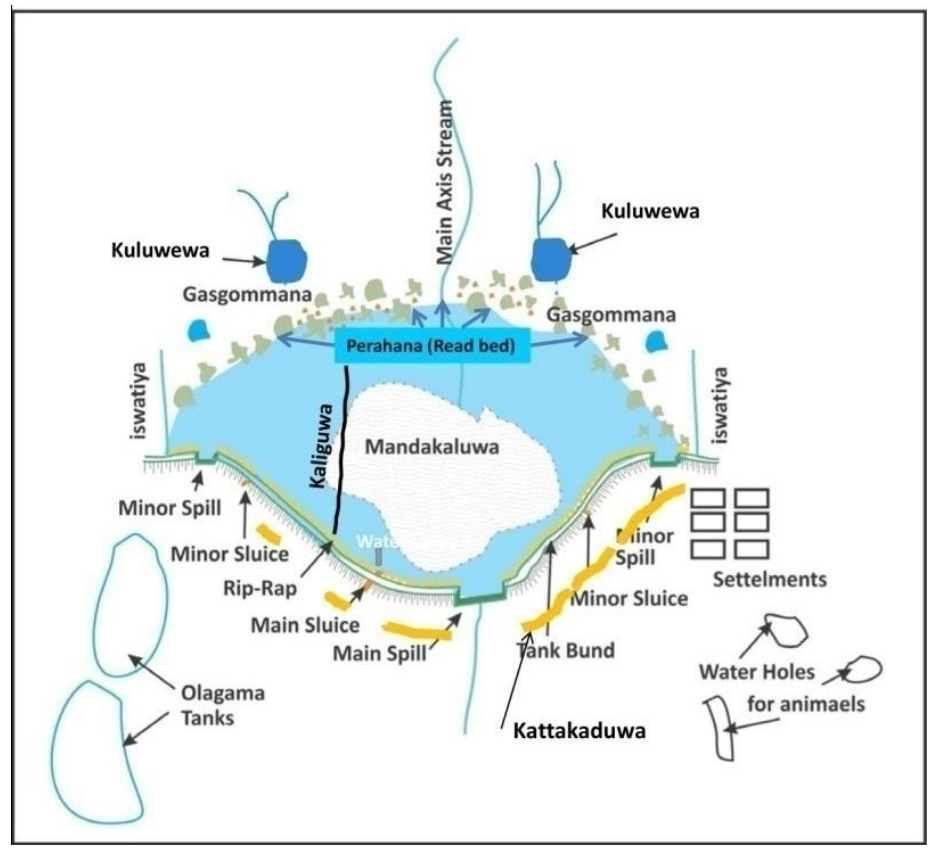

Figure 4. Components of a village tank and their relative positions in the small tank village in Sri Lanka (adapted from Tennakoon, 2015a)

Wewa/ small tank / small reservoir is the main element of tank cascade system and Wewa refers to an artificial lake or a pond for storing water on the surface of the ground, which has 
been constructed by local people at a geographically suitable location using their indigenous skills mostly during ancient times (Nawaratne and Gunawardena, 1999). Gilliland et al., 2013 showed that the majority of these tanks were constructed during the period of the Anuradhapura kingdom (377 BCE to $1017 \mathrm{CE}$ ). In fact, the tanks in dry and intermediate zone in Sri Lanka is not just water collecting vessels but can be considered as a special ecosystem considering its diverse functions. Ancient people used to get drinking water from a separate place called 'Diyamankada' of tank where they have planted Kumbuk trees (Terminalia arjuna) and this place is open to wind and as a result, there are many ripples in the water. Terminalia Arjuna is believed to purify and cool the water, and it has an ability to reclaim saline and alkali soils and reduce soil erosion on banks (Agroforestry database). Ripples generating in the water has also capacity to purify the water. Moreover, this place ('Diyamankada') is far away from bathing places (Nana Mankada), drinking places for cattle (Boradiyamankada) and cloth washing places (Radamankada) (Dalupota 2005). Even when the water quantity is less in the tank, villagers were used to get the water to a clay pot, filtered using piece of cloth and add Ingini (Strychnos potatorum) seeds to purify the water. According to the villagers (personal communication with Uttimaduwa villages in Anuradhapura), Ingini (strychnos potatorum) seeds have the capability to settle down the clay and other suspended matter in the water and soften it. In a study done by Muthuraman et al. (2013) showed the ability of strychnos potatorum to reduce the turbidity by greater than $87 \%$ as it contains anionic polyelectrolyte. Therefore, we can argue that the early people lived in dry and intermediate zone used soft good quality water for drinking. However after introduction of groundwater wells to the dry zone in 1950s, people used groundwater as a source of drinking water.

\subsection{Components of Wewa/ Tank and Their Roles in Managing the Water Pollutants}

Tanks/ Wewa consists of some remarkable bio-engineering structures in order to conserve the soil, control water flow and purifying water. Schematic representation of components of small tank (Tennakoon, 2015) is shown in figure 4 while we try to show the tank profile and its components using figure 5. Proper functioning of these components, the earthen dam (We-kanda), sluice gates (Sorrowwa), spillways (Pita Wana), valve pit (BissoKotuwa), iswetiya (upstream conservation land), gasgommana (upstream wind barrier made of tree plantations), kattakaduwa (downstream wind barrier, located in between the sluice and paddy), tisbamme (land strip around the hamlet for protection), Thaulla (upper peripheral gentle sloping land) and wew ismaththa (closer catchment) ensure the better quality, quantity and sustainability of the water for the tank/wewa. Table 1 summarizes the functions of different components of the tank in relation to water quality improvements while figure 6 shows the successions of water quality improvements in a small tank system as a whole. 
Table 1. Functions of different components of the tank in relation to water quality

\begin{tabular}{|c|c|}
\hline Tank components & Functions \\
\hline Wew Ismaththa (closer catchment) & $\begin{array}{l}\text { Increase the groundwater table through infiltration } \\
\text { and gradual release of water to the tank. } \\
\text { Filter sediments and adsorption of pollutants }\end{array}$ \\
\hline Thaulla (upper peripheral gentle sloping land) & $\begin{array}{l}\text { Consist of Perahana and Gasgommana } \\
\text { Reduce the velocity of flow of water reaching to the tank. } \\
\text { Silt trapping action. } \\
\text { Pollutants retaining action and adsorption of pollutants. } \\
\text { Wind barrier. } \\
\text { Cooling the water. }\end{array}$ \\
\hline Iswetiya or Potawetiya & $\begin{array}{l}\text { Prevent sediments (eroded soil) entering from upper } \\
\text { land slopes to the tank }\end{array}$ \\
\hline Godawala and Kuluwewa & $\begin{array}{l}\text { Trap sediments reaching through the ephemeral streams } \\
\text { Supply water to wild animals }\end{array}$ \\
\hline Kattakaduwa (Interceptor) & $\begin{array}{l}\text { Salt trapping action } \\
\text { Minimize seepage of the bund (dam) } \\
\text { Wind barrier }\end{array}$ \\
\hline Kata sorrowwa/ Kumba sorrowwa & Release of low saline water to the paddy fields \\
\hline Natural spillway opening to rock outcrop area & Control soil erosion \\
\hline Flora along the Kiul ela & Trapping excess nutrients and salts \\
\hline
\end{tabular}

\subsection{Components of the Tank in Relation to Water Quality Improvement}

\subsubsection{Wew Ismaththa (Closer Catchment)}

There was essentially an upstream land area dedicated to the tank from which water drains to the tank (closer catchment). The extent of this area depends on the water spread area of the tank and this area is maintained as a forest in the past. At present, the closer catchment is very rarely observed in small tanks. Kuluwawa and ephemeral streams are generally located in Wew Ismaththa (Figure 3). Wew Ismaththa is protected and cutting trees and chena cultivation (slash and burn cultivation) is prohibited. The purpose of the area was to increase the groundwater table through infiltration and thereby gradual release of water to the tank during the dry season is expected (Hitinayake et al., 2008, Geekiyanage and Pushpakumara, 2013). Farmers under the headmen of the village were used to grow trees in these areas such as Weera (Drypetes sepiaria), Kumbuk (Terminalia arjuna)), Palu (Manilkara hexandra), Mee (Madhuca longifolia), Ahala (Cassia fistula), Thibiri (Diospyros malabarica), etc. and establish vines such as Kobbawel (Allophylus zeylanicus), Eraminiya (Ziziphus oenoplia) and Thiththawel (Anamirta cocculus) thinking that these will absorb more water during the rainy season and drain those absorbed water to the tank slowly. The resulting biotic environment is an ideal place for diverse macro and micro fauna. These organisms along with trees can purify water from upstream tank command areas in this system. Plants in the biotic-environment can absorb herbicide molecules sorbed onto organic matter. Soil microorganisms can degrade the herbicide molecules. According to Michael and Neary (1993) 
some herbicides like glyphosate showed not to leach at all and remain tightly sorbed onto organic complexes. Tree roots and enhanced level of soil organic matter from tree litter improve the soil structure, aggregate stability and promote faunal activity leading to higher macro porosity so that infiltrated water pass through the soil matrix (BarguésTobella et al., 2014; Ellisona et al., 2017). This environment filter sediments and pollutant adsorbed to the sediment particle may not then reach to the tank water. Thus closer catchment had a higher potential to clean the drainage water and if this area is re-established and conserved as in the early days, there is still a potential to improve the tank water quality even though upstream area is heavily cultivated with recommended doses of agro chemicals following integrated nutrient and pest management techniques.

\subsubsection{Thaulla (Upper Peripheral Gentle Sloping Land)}

Waters discharged from the upper tank and drainage excess from upper stream paddy fields are received by the tank at downstream through an area termed as 'Thaulla' (Mahatantila et al., 2007). This micro-catchment region is partly covered with water but completely flooded only during rainy seasons. As shown in the figure 4, 5, and 7, areas where Gasgommana and Perahana are located can be considered as Thaulla. Thaulla does not allow water flow from the upstream area/ upper catchment directly reaching it as fast flowing stormwater into the tank. This area consists of arrays of bushes such as Boolpana (Glycosmis angustifolia), kooratiya (Phyllanthus polyphyllus), Tharana (Tarenna asiatica), Maila (Bauhinia racemosa), Pila (Tephrosia purpurea), Ankenda (Acronychia pedunculata), Ulkenda (Polyalthia korinti) Korakaha (Memecylon umbellatum), etc, and the trees such as Nabada (Vitex leucoxylon), Dunuke (Pandanus foetidus), Mee(Madhuca longifolia), Damba (Syzygium gardneri), Kumbuk (Terminalia arjuna) etc. In addition, sedges such as Hambupan (Typha angustifolia), Thunhiriya (Schoenoplectus grossus), Gal ehi (Cyperus corymbosus), Borupan (Eleocharis dulcis) and Vatakeyya (Pandanus species) and also different kind of climbers such as Kaila (Phyllanthus reticulatus) Katukeliya (Caesalpinia bonduc), Kalawel (Derris parviflora) Bokalawel (Derris scandens) (IUCN 2015) and grasses are abounded in these land mass. These florae have an ability to trap sediments and absorb pollutants and negate their toxicity reaching to the tank. Moreover, these strip of trees (Gasgommana) act as a wind barrier and also lower the temperature of the water in the tank. Mahatantila et al., 2007, using Malagane tank as an example in Deduru Oya river basin showed that pollutants draining into the tank can be effectively controlled by the Thaulla. Most water quality parameters except phosphorus showed a decreasing trend when water passes through Thaulla area. It has also been shown that $\mathrm{Mg}, \mathrm{Na}$, and $\mathrm{Ca}$ in a decreasing concentration in soils of Thaulla area towards the water spread area in Ulankulama tank at Maradankadawala in Anurahdapura and their concentration is higher in Thaulla area when compared to the normal values of the surrounding soils (Abeysingha et al. 2016). These results suggest that Thaulla, can act approximately as an active 'constructed wetland' which efficiently removes pollutants in order to sustain the system. Role of constructed wetland and functions of wetland have been shown by many authors (Mazumdar and Das 2015, Jia et al., 2016 etc.). Wetlands can be referred to as the interface of aquatic and terrestrial ecosystems, forming specialized ecosystems where complex ecological processes occur due to the interactions between water, vegetation and 
soils (Naiman and Henri, 1997). Since Thaulla is submerged with water for about 3 to 5 months during rainy season ( November to Febrary), and then drying steadily during the other months, the Thaulla and tank water spread area its ecosystem can also be considered as a special wetland.

Mahatantila et al. (2007) and Abeysingha et al. (2016) showed the chemical precipitation function of Thaulla area and other wetland functions need to be tested by doing experiments to understand the degree of occurrence of those functions. It has been shown ecosystem services such as water storage and flood protection, biodiversity support, carbon (C) storage and sequestration, and water quality improvement benefits provided by the wetland and riparian buffers (Fennessy and Craft, 2011; Marton et al. (2014). However, not all wetlands equally provide the same functions. Marton et al. 2014 showed the lower water quality improvement functions and $\mathrm{C}$ pools in restored wetlands than in natural wetlands by taking 10 restored and five natural depressional wetlands in northern Indiana and four restored and four natural riparian buffers in central Indiana. Thaulla in most of the small tanks are just like the natural meadow with trees at the peripary, though it is submerged with water for about 3 to 4 months. It has been shown that many species of plants/ trees absorb contaminants such as lead, cadmium, chromium, arsenic, and various radionuclides from soils (Tangahu et al. 2011). Contaminants in water are reduced or removed by wetland systems by mechanisms including sedimentation, filtration, chemical precipitation and adsorption, microbial interactions and uptake by vegetation (Kivaisi, 2001). Similar function may perform by the trees and other aquatic plants naturally growing at the periphery of Thaulla area of the tank. Ancient people used to maintain the Thaulla area and used the water of these small tanks for all the purposes.

Ancient people knew that the life span of the tank depends on the functions of Thaulla. Therefore, entering into this area is customarily prohibited to anybody except the Ayurveda doctor in the village to collect medicinal plants. Protection of this areas is a duty of the headmen of the farmers or the village headmen (Dalupota, 2005). However at present, it is rather difficult to find out the good extent of Thaulla in most of the tanks and also conservation of this area is neglected due to overexploitation of the resources and ignorance. This degradation of Thaulla area results in lowering the water holding capacity of the tank and impair the water quality. If there was a possibility to drink surface water of the tanks as earlier, we might not adversely exposure to these cadmium, arsenic or excessive iconicity because of the pollutant degrading functions of the Thaulla area of the tank.

\subsubsection{Kattakaduwa (Interceptor)}

This is an elongated murky meadow with turbid water in between the outer toe of a tank bund and paddy field. When halophytes such as mi (Bassia longifolia), kumbuk (Terminalia arjuna), lunuwarana (Creteva adansonii), thimbiri (Diospyros malabarica), val beli (Lumnitzera litterea), and vetakeyya (Pandanus kaida) are grown in over the rim of the medow salts on the water is reduced (Tennakoon, 2015b). In a preliminary study done by Madduma Bandara et al., 2010 showed that the higher EC levels recorded in Kattakaduwa area in all tanks in Navodagama, Kahagollewa and Parana Halmillewa cascades in 
Anuradhapura district. This observed higher salinity concentration is due to seepage of water from dead storage area of the tanks where there is a buildup of salinity in most of the tanks (Madduma Bandara 2010). However, this Kattakaduwa area also acts as a downstream wind barrier and helps to protect soil from erosion as majority of species consists with well-developed root systems. Hence these ecofriendly structures improve the water quality of the command area by removing excess salts, nutrients and sediments. This command area is the catchment area for the next downstream tank in tank cascade system.

Iswetiya or Potawetiya is an up stream soil ridge made at either side of the tank bund to avoid sediment particles entering from upper land slopes towards the tank (Figure 3). In addition, Godawala and Kuluwewa were constructed to trap sediments reaching from the ephemeral stream to the tank. Godawala which is found in association with a small tank, is a manmade waterhole. Whereas Kuluwewa a small tank or pond above large reservoirs trap sediments and provide water for cattle and wild animals which may be a strategy to avoid man-animal conflicts (Figure 3). Construction of these Iswetiya or Potawetiya, Godawala or Kuluwewa ensures the good water quality and arrest siltation of the tank. In addition, villagers used to remove sediments from most silted areas of the tank bed during extended dry spells usually at a frequency of 3 to 5 seasons. This sediment removal (de-siltation) process (Kattikapeema in Sinhala folkloristic term) has been considered as a common responsibility of the downstream water users and carried out through community volunteer work. However, de-siltation process was restricted only to well-identified locations of the tank bed and a sediments layer of not more than $15 \mathrm{~cm}$ deep and the materials removed from the tank bed was not placed on the dam (Dalupota, 2005). Further, early engineers constructed mud sluice to remove the silt emptying the tank. Moreover, the place of the spillway of tank is generally designed to open to a low rock outcrop area (Panabokke et al., 2002) so that erosion is minimized from the water released from the tank. Hence, tank water was sustainably used for drinking, bathing, washing and irrigation. Raising the dam or spill was not required as at present to accommodate a sufficient quantity of water for irrigation.

In the downstream command area of a tank where paddy is grown, old natural stream is used as a common drainage line (locally termed as Kiul ela) which collects and removes seepage water usually carry dissolved ions (Dharmasena, 2004). Accumulation of dissolved ions, especially $\mathrm{Na}^{+}$, locally pause risks of salinization and iron pollution within of the local command area and Kiul ela facilitates faster drainage minimising such risks (IUCN 2015). In addition, tree species such as karanda (Pongamia pinnata), mee (Madhuca longifolia), mat grass (Axonopus species), ikiri (Acanthus ilicifolius), vetakeya (Pandanus odoratissimus) etc., which are capable of trapping excess nutrients and salts are planted along the Kiul ela. This vegetation apparently contributes to purification of drainage water to a considerable extent even within the local command area. Drainage water subsequently reaches to the next downstream tank through the Wew Ismaththa (closer catchment) and Wew Thaulla within the cascade system. However, the reservation of the next tank or Wew Ismaththa (closer catchment) of the cascade begins just below the paddy fields of the upper tank. Dharma-wardana $(2015,2017)$ stated that the origin of kidney disease was linked to water with high ionicity damaging the membranes in the tubules and other components of the 


\section{Macrothink}

kidney via the Hofmeister mechanism. Ionicity of water substantially is reduced in tank water when the water passes though these Kattakaduwa - Kiwul Ela system. At present, these systems are neglected in many tanks/cascade systems that might result in increase salinity.

Fluoride in water is also considered to be a causal factor for CKDu. Chandrajith et al. (2011) showed that increased $\mathrm{Na} / \mathrm{Ca}$ ratio, promotes formation of complexes with $\mathrm{Na}$ ions which reduces both the toxicity of fluoride ions in the human body and the absorption of $\mathrm{Ca}^{2+}$. Conversely, higher $\mathrm{Ca}^{2+}$ activity results in possible lesions on tubular cells leading to their death thus aggravating the damage caused by fluoride. Tank water with the influence of above mentioned ecosystem in tank cascade system may contain less $\mathrm{Ca}^{2+}$ as the trees and shrubs absorb $\mathrm{Ca}^{2+}$ in tank water. In addition, groundwater is in longer and intimate contact with subsurface rocks than surface tank water. Therefore, groundwater is generally found to be higher in fluoride concentration depending on the mineralogical compositions of the underground materials (Edmunds and Smedley 2013). The Fluoride concentration of deep and shallow groundwater in Anuradhapura area varies from 0 to $2.5 \mathrm{mg} / \mathrm{l}$. According to the Sri Lankan drinking water standards, the Fluoride level should be less than $1.5 \mathrm{mg} / \mathrm{l}$. The occurrence of high fluorides is primarily connected to the geology of the area (Wijesekara 2016). Fluoride in lower concentration becomes nephrotoxic in the presence of hard water Dharma-wardana (2017). Since tank water has generally low concentration of Fluoride, we believe that use of tank water for drinking under the natural agro ecosystem may not be a causal factor for ill-health associated with fluoride.

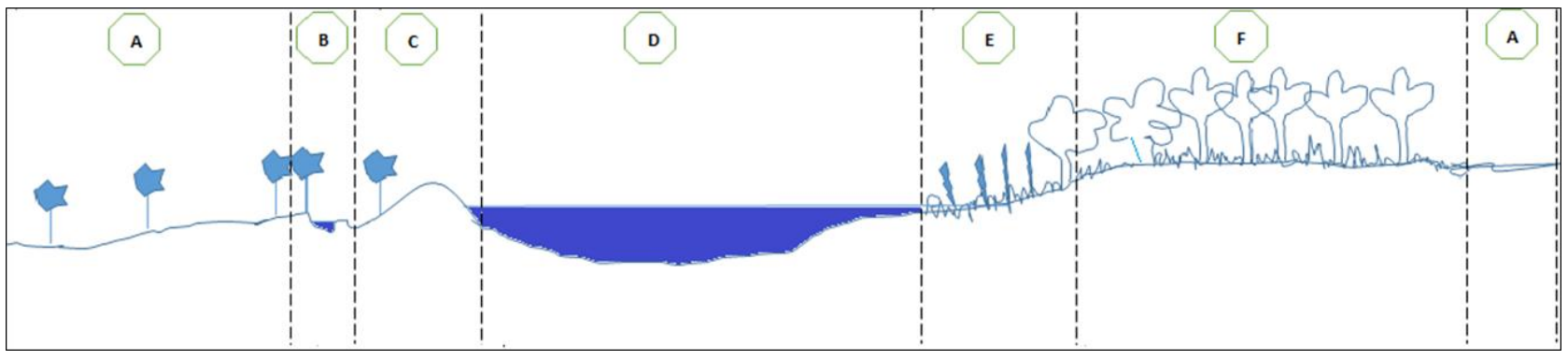

Figure 5. Schematic representation of the profile of small tank and its components (Produce by the Authors)

A : Command area specially paddy ; B : Kattakaduwa; C: Earthen Dam ; D: Water spread area of the tank; E: Thaulla ; F: Closer catchment/ Wew Ismaththa 
Closer catchment/

Wew Ismaththa

Infiltration of water to the soil and gradual release of water to the tank. Pollution control and filter sediments

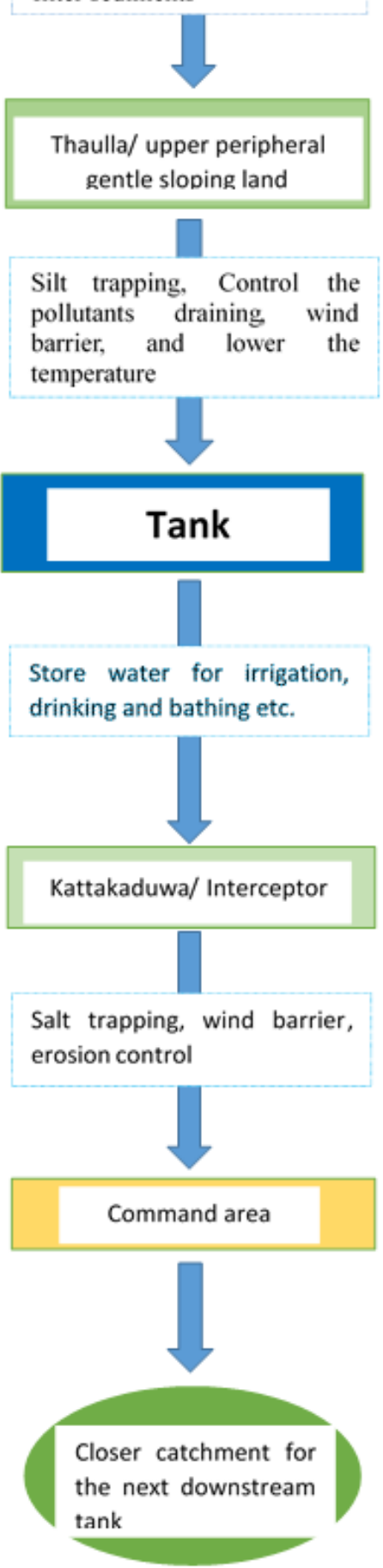

Figure 6. Key functions of the main components of a small tank (Produce by the 


\section{Authors)}

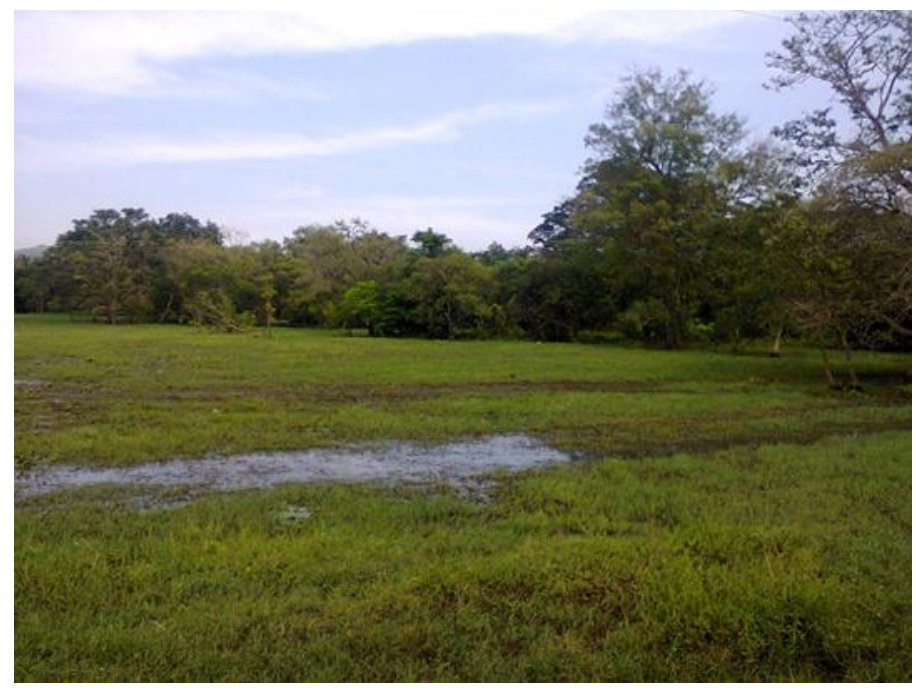

Figure 7. Thaulla area of ulankulama tank, Anuradhapura in Sri Lanka (Produce by the Authors)

The benefit of tank cascade system is that the downstream tank captures the excess water from the tank above. Thus, water is not wasted and but recycled. Importance of this system has been described by few publications such as Panabokke et al., 2002; Madduma Bandara 1995; Sakthivadivel et al., 1997; Siriweera, 2001; Somapala, 2001; Somasiri, 2001; etc. However, this age old ecofriendly concept/practice had not been taken into consideration during irrigation system restoration and settlement projects in 1950s, 1960s and 1970s where short sighted efforts have been increasingly made by the water resources managers. It is widely accepted that the ancient irrigation system in the dry-zone of Sri Lanka was largely developed during the period up to 12th century. The system faced a decline from 13th century to 19th century (Panabokke, 1999), although the system did not completely collapse. The number of operational and abandoned small tank within each province is shown in table 2 . If all these tanks were in operation, we hope there is no need of extraction of groundwater for drinking or farming purposes. Use of groundwater for drinking has been one of the causes of CKDu because of its higher ionicity. We hope still there is a possibility to adopt these tank cascade system and integrate the ancient technology with the novel watershed and water resources management techniques so that we could minimise predisposal factors to CKDu.

Table 2. Number of operational and abandoned small tank within each province (adopted from Panabokke et al., 2002)

\begin{tabular}{|l|l|l|l|}
\hline \multirow{2}{*}{ Province and area $\left(\mathrm{km}^{2}\right)$} & \multicolumn{2}{|l|}{ Number of small tanks } & Total \\
\cline { 2 - 4 } & Operating & Abandoned & \\
\hline Northern 3,709 & 608 & 816 & 1,424 \\
\hline North central 10,365 & 2,095 & 1,922 & 4,017 \\
\hline North western 7,760 & 4,200 & 2,273 & 6,473 \\
\hline Southern 2,849* & 653 & 757 & 1,410 \\
\hline Lower Uva 2,901* & 16 & 543 & 559 \\
\hline Eastern ( South of Mahaweli) 3,885* & & 1,017 & 1,017 \\
\hline Eastern ( North of Mahaweli) 3,885* & 48 & 425 & 473 \\
\hline
\end{tabular}




\begin{tabular}{|l|l|l|l|}
\hline Total & 7,620 & 7,753 & 15,373 \\
\hline
\end{tabular}

*Includes only the dry zone part of the province.

Note: The data is based on 1995 Department of Agrarian Services (DAS) data bank and 1982 ABMP maps

The Mahaweli development project is the largest irrigation and hydropower project in Sri Lanka which started its work extensively by 1977 and diverted water to the dry zone. It is reported that by the 2006 the landuse pattern of dry zone (Mahaweli system B, C, G and H) completely changed. As the centralized large-scale schemes were considered to be more efficient than the decentralized small systems, a number of small tank cascades were replaced by large reservoirs and high capacity feeder channels (Geekiyanage and Pushpakumara 2013). Most of the large reservoirs recently built were silted considerably and water quality has been impaired (Hewawasam, 2010) when compared to the small tanks in tank cascade system. Larger tanks at the end of tank cascade will not be silted in a larger magnitude as the total system is amalgamated with the ecosystem. Analysis of sediment profiles at four tank cascade system north of Anuradhapura suggests that after the abandonment of the ancient capital Anuradhapura in the 11th century $\mathrm{CE}$, which was a period characterized by socio-economic instability and increased climatic fluctuations, severe erosion did not affect the decentralize managed small tanks (Bebermeier et al., 2017).However, we could not find considerable studies on tank siltation in dry and intermediate zone in the country except the a simple study conducted by Dharmasena (1992). Therefore, we suggest a siltation study of tank cascade with geochemical analysis of silted layers.

Sediments reaching from the catchment reduce the water holding capacity of the tank and spoil the water quality. Because, these surface sediment has the capability in accumulation of heavy metals, acting as both sinks for and sources of pollutants (Santschi et al., 1997; Chen et al., 2016) while sediment itself is considered as a water pollutant. However, the strategies used by the earlier local people such as the constructions of godawala, Thaulla, potawati etc. may considerably trap the sediments thereby improve the water quality and quantity of the tank.

\section{Water Quality of Tanks/ Wewa in Dry and Intermediate Zone of Sri Lanka}

Bandara et al., 2008 reported higher concentration of $\mathrm{Cd}$ in some tanks in the north-central province in Sri Lanka such as Kumbichchankulama $(0.05 \mathrm{mg} / \mathrm{l})$, Thuruwila $(0.06 \mathrm{mg} / \mathrm{l})$, Karapikkada (0.06 mg/l). However, Chandrajith et al., 2011 found very low levels (average $0.004 \mu \mathrm{g} / \mathrm{l}$ ) of $\mathrm{Cd}$ in dry zone reservoirs located within the CKDu prevalent areas and also Diyabalanage et al. (2016) reported lower level of Cd ( average $0.216 \mu \mathrm{g} / \mathrm{l}$ ) in six dry zone tanks. Moreover, Perera et al. (2016) analyzed the As and Cd concentration in water and sediments, as well as in fish tissues in Malwathu oya river basin upto Nachchaduwa in Anuradhapura district. Arsenic concentrations in the canals where water divert to the river from paddy land area ranged annually from 111 to $498 \mu \mathrm{g} / \mathrm{L}$ and $\mathrm{Cd}$ concentrations ranged from 76 to $245 \mu \mathrm{g} / \mathrm{L}$ while As and Cd concentrations in the upper Malwathu Oya (first $70 \mathrm{Km}$ of the river) ranged from 1 to $48 \mu \mathrm{g} / \mathrm{L}$ and 1 to $134 \mu \mathrm{g} / \mathrm{L}$ respectively. They also found that both $\mathrm{As}$ and $\mathrm{Cd}$ concentrations were higher in paddy-area-sites than forest-area-sites and further, the mean As and Cd concentration in all sampling sites during first inter-monsoon 
and second inter-monsoon were higher than the recommended values (As, $10 \mu \mathrm{g} / \mathrm{L} ; \mathrm{Cd}, 3$ $\mu \mathrm{g} / \mathrm{L}$ ) in drinking water proposed by WHO, 2006. Water of Malwawthu Oya is associated with the waters of nearby cascades such as Ulagalla cascade. These higher concentration of As and $\mathrm{Cd}$ indicates the excessive use of agro chemicals containing $\mathrm{As}$ and $\mathrm{Cd}$ and also malfunctions of the components of tank cascade system in the area. Further, As and Cd has shown to be factor for the genesis of CKDu.

Several studies reported the overuse of agricultural chemicals by farmers in many parts of Sri Lanka (Selvarajah and Thiruchelvam, 2007; Padmajani et al. 2014, Perera 2016). Most of the tanks in dry and intermediate zone of the country shows the signs of eutrophication. The $\mathrm{PO}_{4}{ }^{3-}$ concentrations of six tanks in Mahakanamulla cascade in Anuradhapura were greater than the EPA suggested critical value $\left(0.08 \mathrm{mgL}^{-1}\right)$ for the development of eutrophication (Wijesundara et al. 2014). However, nutrient accumulation $\left(\mathrm{NO}_{3}--\mathrm{N}, \mathrm{PO}_{4}{ }^{3-} \mathrm{P}\right.$ and $\left.\mathrm{K}^{+}\right)$in Thirappane cascade in Anuradhapura showed higher concentration just after the fertilizer application for paddy cultivations in the area. Phosphate in drinking water is also a strongly Hofmeisteractive ion and regulatory authorities has not stipulated maximum allowable level in drinking water (Dharma-wardana 2017).

Higher concentration of nutrients lead to eutrophication of tanks and it results in reducing the biodiversity of the tanks. The destructive algal blooms resulted from eutrophication yield toxic substances that kill fish and cause disease in animal and humans (Schoumans et al., 2014). Cyanobacteria a kind of blue green algae grown in nutrient rich water and produce toxins that affect humans and animals. Impacts of extracts of cyanobacteria obtained from Padaviya reservoir and canals in Sri Lanka on mice fed by these extracts showed acute tubular necrosis in mice. These observations focused on cyanobacterium toxins as another potential nephrotoxin which may be a factor to cause CKD (Shihana et al., 2012). Sanjeevani et al., 2017 assessed the pollutants levels in agricultural areas in part of North Central Province (Madawachchiya-Ranorawa-Elayapattuwa-Hurathgama-Nawagattegama, central coordinates $8^{\circ} 17^{\prime} 35.43^{\prime \prime} \mathrm{N} 80^{\circ} 14^{\prime} 24.79^{\prime \prime} \mathrm{E}$ ) in Sri Lanka and found that soil in the area are uncontaminated to moderately contaminated of the elements such as $\mathrm{Cu}, \mathrm{Pb}, \mathrm{Ni}, \mathrm{Zn}$, and $\mathrm{Cd}$. Further, they concluded that agricultural practices has a great impact on the level of Cd and $\mathrm{Zn}$ contamination in the soil. These findings further corroborate the importance of reestablishment of essential components of tank cascade system and devastating effects of excessive use of agrochemicals.

\section{Conclusion}

Etiology for CKDu in dry zone of Sri Lanka is multifactorial and is related to water. Use of mainly unfavorable ground water leads to CKDu. Ancient people in the CKDu prevalent area used surface water of tanks in tank cascade system. This review showed the diverse functions of the Thaulla, wew ismaththa, kattakaduwa, godawala etc. in relation to improving water quality. Concentration of some nutrients and metallic elements decrease when water flow through the Thaulla area of the tank. Thaulla and wew ismaththa were customarily conserved by the ancient people and flora and fauna in these areas considerably improve the water quality. However, at present, these components in small tanks are not present or their 
functions are ignored. Overuse of the agrochemicals are reported in crop lands and signs of eutrophication are observed in small tanks at present. The reconstruction of ecofriendly structural components of tanks and reestablishment of tank cascade system in the area would help to combat the spreading of CKDu in dry and intermediate zone of the country.

\section{Suggestions}

The tanks from which inhabitants of dry zone obtain drinking water need to be ecologically rehabilitated and cultivation of Thaulla and wewismaththa should be prohibited. Tree species such askaranda (Pongamia pinnata), mee (Madhuca longifolia), mat grass (Axonopus species), ikiri (Acanthus ilicifolius), vetakeya (Pandanus odoratissimus) etc. which are capable of trapping excess nutrients, pollutants and salts should be cultivated in Thaulla and wewismaththa of the tanks. Salt trapping trees and sedges should also be cultivated in Kattakaduwa area of the tank cascade system. Until the water in tanks are proved to be safe and devoid of toxic elements such as $\mathrm{As}$ and $\mathrm{Cd}$, excess of $\mathrm{Ca}, \mathrm{Mg}$ and $\mathrm{PO}_{4}{ }^{-2}$, good quality water should be made available. In this regard Reverse Osmosis plants, Rainwater harvesting may be used till the surface water is in good quality for drinking. It is also suggested to dedicate few more tanks with above mentioned ecosystem components to supply only drinking water for the public. Sri Lanka does not have formally approved water policy though it has been discussing since 1982 (IUCN, 2015). Sri Lanka needs a water policy formulation addressing the water quality issues and identifying the tank cascade system as a lifeblood of the dry zone rather than water of trans-basin water diversion system such as Mahaweli system. Components of the tanks need to be well delineated and recognized as vital areas in improving the water quality. Long term studies to test the water pollutant status of the entire cascade system is also suggested.

\section{There is no any conflict of interest among the authors}

\section{References}

Abeysingha, N. S., Jayenethithi, J. P. H. U., Kosgollegedara, E. J., \& Hammer, S. (2016/17). Variation in Soil Quality Parameters in the Thaulla Area of a Small Reservoir - A Case Study of Ulankulama Tank at Anuradhapura, Sri Lanka, Journal of Agro-Physics (In Press).

Orwa, C., Mutua, A., Kindt, R., Jamnadass, R., \& Simons, A. (2009). Agroforestry Database: a tree reference and selection guide version 4.0. World Agroforestry Centre, Kenya, Retrieved from http://www.worldagroforestry.org/treedb/AFTPDFS/Terminalia_arjuna.PDF

Awsadahami, U. B. (2010). The ancient irrigation system Past and present, National conference on Irrigation system for rural sustainability, Sri Lanka foundation institute, Independent square Colombo07, 09 December 2010.

Bandara, J. M. R. S., Senevirathna, D. M. A. N., Dasanayake, D. M. R. S. B., Herath, V., Bandara, J. M. R. P., Abeysekara, T., \& Rajapksha, K. H. (2008). Chronic renal failure among farm families in cascade irrigation systems in Sri Lanka associated with elevated dietary cadmium levels in rice and freshwater fish (Tilapia). Environment Geochemistry and Health, 30, 465-478. https://doi.org/10.1007/s10653-007-9129-6 
Bandara, J. M. R. S., Wijewardena, H. V. P., Liyanege, J., Upul, M. A., \& Bandara, J. M. U. A. (2010). Chronic renal failure in Sri Lanka caused by elevated dietary cadmium: Trojan horse of the green revolution. Toxicology Letters, 198(1), 33-39.

https://doi.org/10.1016/j.toxlet.2010.04.016

Bargués, T. A., Reese, H., Almaw, A., Bayala, J., Malmer, A., Laudon, H., \& Ilstedt, U. (2014). The effect of trees on preferential flow and soil infiltrability in an agroforestry parkland in semiarid BurkinaFaso. Water Resources Research, 50, 3342-3354. http://dx.doi.org/10.1002/2013WR015197.

Bebermeier, W., Meister, J., Withanachchi, C. R., Middelhaufe, I., \& Schütt, B. (2017). Tank Cascade Systems as a Sustainable Measure of Watershed Management in South Asia. Water, 9 , 231. https://doi.org/10.3390/w9030231

Chandrajith, R., Dissanayake, C. B., Ariyarathna, T., Herath, H. M. J. M. K., \& Padmasiri, J. P. (2011). Dose-dependent $\mathrm{Na}$ and $\mathrm{Ca}$ in fluoride-rich drinking water-another major cause of chronic renal failure in tropical arid regions. Science of Total Environment, 409, 671-675. https://doi.org/10.1016/j.scitotenv.2010.10.046

Chen, Y. M., Gao, J., Yuan, Y. Q., Ma, J., \& Yu, S. (2016). Relationship between heavy metal contents and clay mineral properties in surface sediments: Implications for metal pollution assessment. Continental Shelf Research, 124, 125-133.

https://doi.org/10.1016/j.csr.2016.06.002

Dalupota, M. K. (2005). Tank and the culture, Explorations of tank related experience of villagers of Ahatuwewa Divisional Secretariat tank village (Sinhala edition). S. Godage and Brothers, Maradana road Colombo 10.

Dharmasena, P. B. (1992). Magnitude of sedimentation in village tanks. Tropical Agriculture, Dept. of Agriculture, Peradeniya, Sri Lanka, 148, 97-110.

Dharmasena, P. B. (2004). Small tank heritage and current problems. In: Aheeyar, MMM. Eds Small Tank Settlements in Sri Lanka. Kobbakaduwa Agrarian Research and Training Institute, Colombo, Sri Lanka p. 31-39.

Dharmasena, P. B. (2010). Essential components of traditional village tank systems. In: Proceedings of the National Conference on Cascade Irrigation Systems for Rural Sustainability. Central Environmental Authority, Sri Lanka, 9 December 2010.

Dharma-Wardana, M. W. C., Amarasiri, S. L., Dharmawardene, N., \& Panabokke, C. R. (2015). Chronic kidney disease of unknown aetiology and ground-water ionicity: study based on Sri Lanka, Environment. Geochemistry and Health, 37, 221-31.

https://doi.org/10.1007/s10653-014-9641-4

Dharma-wardana, M. W. C. (2017). Chronic Kidney Disease of Unknown etiology (CKDu) and multiple-ion interactions in drinking water, Geochemistry and Health.

Diyabalanage, S., Abekoon, S., Watanabe, I., Watai, C., Ono, Y., Wijesekara, S., Guruge, K. S., \& Chandrajith, R. (2016). Has irrigated water from Mahaweli River contributed to the 
kidney disease of uncertain etiology in the dry zone of Sri Lanka? Geochemistry and Health, 38, 679-690. https://doi.org/10.1007/s10653-015-9749-1

Dissananyake, D. M., Jayasekera, J. M. K. B., Ratnayake, P., Wickramasinghe, W., \& Radella, Y. A. (2011). The Short-Term Effect of Cyanobacterial Toxin Extracts on Mice Kidney Proceedings of the Peradeniya University Research Sessions, Sri Lanka, Vol. 16, November 2011.

Edmunds, W. M., \& Smedley, P. L. (2013). Fluoride in natural waters In Selinus O, Alloway B, Centeno JA, Finkelman RB, Fuge R, Lindh U, Smedley PL (eds.) Essentials of medical geology, 2nd edn. Springer, The Netherlands, 311-336.

https://doi.org/10.1007/978-94-007-4375-5_13

Ellisona, D., Morris, C. E., Locatelli, B., Sheil, D., ... Sullivan, C. A. (2017). Trees, forests and water: Cool insights for a hot world. Global Environmental Change, 43, 51-61.

https://doi.org/10.1016/j.gloenvcha.2017.01.002

FAO (2018). Globally Important Agricultural Heritage Systems combining agricultural biodiversity, resilient ecosystems, traditional farming practices and cultural identity, Retrieved from http://www.fao.org/3/BU612EN/bu612en.PDF

Fennessy, S., \& Craft, C. (2011). Agricultural conservation practices increase wetland ecosystem services in the Glaciated Interior Plains. Ecological applications. https://doi.org/10.1890/09-0269.1

Gifford, F. J., Gifford, R. B., Eddleston, M., \& Dhaun, N. (2017). Endemic Nephropathy Around the World, Review, Kidney International Reports, 2(2), 282-292.

https://doi.org/10.1016/j.ekir.2016.11.003

Gilliland, K., Simpson, I. A., Adderley, W. P., Burbidge, C. I., Cresswell, A. J., Sanderson, D. C. W., ... Adikari, G. (2013). The dry tank: Development and disuse of water management infrastructure in the Anuradhapura hinterland, Sri Lanka. Journal Archaeological Science, 40, 1012-1028. https://doi.org/10.1016/j.jas.2012.09.034

Geekiyanage, N., \& Pushpakumara, D. K. N. G. (2013). Ecology of ancient Tank Cascade Systems in island Sri Lanka. Journal of Marine and Island Cultures, 2, 93-101.

https://doi.org/10.1016/j.imic.2013.11.001

Hewawasam, T. (2010). Effect of land use in the upper Mahaweli catchment area on erosion, landslides and siltation in hydropower reservoirs of Sri Lanka. Journal of National Science Foundation of Sri Lanka, 38(1), 3-14. https://doi.org/10.4038/jnsfsr.v38i1.1721

Hitinayake, G., Silva, D., \& Vithanage, I. (2008). Ecological Farming Systems and Technologies (Sinhala Version). Department of Crop Science, Faculty of Agriculture, University of Peradeniya, Peradeniya, Sri Lanka.

Illeperuma, O. A., Dharmagunawardhane, H. A., \& Herarh, K. P. R. P. (2009). Dissolution of Aluminum from substandard utensils under high fluoride stress: A possible risk factors for chronic renal failures in the North-Central Province. Journal of National Science Foundation 
of Sri Lanka, 37, 219-222. https://doi.org/10.4038/jnsfsr.v37i3.1217

IUCN (2015). Tank ecosystem restoration. IUCN programme on Restoring Traditional Cascading Tank Systems Technical Note 3. Colombo: IUCN, International Union for Conservation of Nature, Colombo, Sri Lanka \& Government of Sri Lanka.

Jayasumana, C., Gunatilake, S., \& Senanayake, P. (2014). Glyophosate, hard water and nephrotoxic metals: are they the culprits behind the epidemic of chronic kidney disease of unknown etiology in Sri Lanka Int. Journal of Environmental Research and Public Health, 11, 2125-2147. https://doi.org/10.3390/ijerph110202125

Jayasumana, M. A. C. S., Paranagama, P. A., Amarasinghe, M. D., Wijewardane, K. M. R. C., Dahanayake, K. S., ... Senanayake, V. K. (2013). Possible link of Chronic arsenic toxicity with Chronic Kidney Disease of unknown etiology in Sri Lanka. Journal of Natural Sciences Research, 3(1), 64-73.

Jayasekara, J. M., Dissanayake, D. M., Adhikari, S. B., \& Bandara, P. (2013). Geographical distribution of chronic kidney disease of unknown origin in North Central Region of Sri Lanka. Ceylon Medical Journal, 58(1), 6-10. https://doi.org/10.4038/cmj.v58i1.5356

Jayatilake, N., Mendis, S., Maheepala, P., \& Mehta, F.R. (2013). Chronic kidney disease of uncertain aetiology: prevalence and causative factors in a developing country. $B M C$ Nephrology, 14, 180-193. https://doi.org/10.1186/1471-2369-14-180

Jia, Z., Tang, S., Luo, W., \& Hai, Y. (2016). Water quality improvement through five constructed serial wetland cells and its implications on nonpoint-source pollution control. Hydrological Sciences Journal, 61(6), 2946-2956.

https://doi.org/10.1080/02626667.2016.1171323

Kivaisi, A. K. (2001). The potential for constructed wetlands for wastewater treatment and reuse in developing countries: a review. Ecological Engineering, 16, 545-560.

https://doi.org/10.1016/S0925-8574(00)00113-0

Lunyera, J., Mohottige, D., Isenburg, M. V., Jeuland, M., Patel, U. D., \& Stanifer, J. W. (2015). CKD of Uncertain Etiology: A Systematic Review. Clinical Journal of the American Society of Nephrology, 11.

Madduma Bandara, C. M. (1985). Catchment ecosystems and village tank cascades in the dry zone of Sri Lanka: a time-tested system of land and water management in Lundqvist, J. et al. (Eds ) Strategies for River Basin Management. Linkoping, Sweden.

https://doi.org/10.1007/978-94-009-5458-8_11

Madduma Bandara, C. M. (1995). Tank cascade systems in Sri Lanka: Some thoughts on their development implications in Haq KA, Wijayaratne CM, Samarasekera BMS (Eds.) Summaries of papers presented at Irrigation Research Management Unit seminar series during 1994. Colombo, Sri Lanka, IIMI 14

Madduma Bandara, C. M., Yatigammana, S., \& Paranawithana, G. (2010). Scientific validation of some traditional land and water management practices under village tank 
cascade system. Economic review, NSF. Retrieved from http://dl.nsf.ac.lk/handle/1/14115

Mahatantila, K., Chandrajith, R., Jayasena, H. A. H., \& Ranawana, K. B. (2007). Spatial and temporal changes of hydrogeochemistry in ancient tank cascade systems in Sri Lanka: evidence for a constructed wetland. Water and Environment Journal, 22(1), 17-24.

https://doi.org/10.1111/j.1747-6593.2007.00077.x

Mazumdar, K., \& Das, S. (2015). Phytoremediation of Pb, Zn, Fe, and Mg with 25 wetland plantspecies from a paper mill contaminated site in North East India. Environmental Science and Pollution Research, 22, 701-710. https://doi.org/10.1007/s11356-014-3377-7

Marton, J. M., Fennessy, M. S., \& Craft, C. B. (2014). Functional Differences between Natural and Restored Wetlands in the Glaciated Interior Plains, Journal of Environmental Quality, 43(1), 409-17. https://doi.org/10.2134/jeq2013.04.0118

Michael, J. L. \& Neary, D. G. (1993). Herbicide dissipation studies in southern forest ecosystems. Environmental Toxicology and Chemistry, 12, 405-410.

https://doi.org/10.1002/etc.5620120303

Muthuraman, G., Sasikala, S., \& Prakash, N. (2013). Proteins from Natural Coagulant for Potential Application of Turbidity Removal in Water. International Journal of Engineering Innovative Technology (IJEIT), 3(1), 278 -282.

Naiman, R. J., \& Henri, D. (1997). The ecology of interfaces: riparian zones. Annual Review of Ecology and Systematics, 28, 621-658. https://doi.org/10.1146/annurev.ecolsys.28.1.621

Navaratne, W. M. U., \& Gunawardena, E. R. N. (1999). Verification of Design Parameters for Operational Studies of Minor Tanks in the Dry zone. Tropical Agricultural Research, 11, $1-18$.

Padmajani, M. T., Aheeyar, M. M. M., \& Bandara, M. M. M. (2014). Assessment of Pesticide Usage in Up-Country Vegetable Farming in Sri Lanka. HARTI Research Report no: 164. Hector Kobbekaduwa Agrarian Research and Training Institute, Colombo, Sri Lanka.

Panabokke, C. R. (1999). The small tank cascade systems of the Rajarata, their settings, distribution pattern and hydrography. Mahaweli Authority - International Irrigation Water Management Institute, Sri Lanka.

Panabokke, C. R., Sakthivadivel, R., \& Weerasinghe, A. D. (2002). Evolution, Present Status and Issues Concerning Small Tank Systems in Sri Lanka. International Water Management Institute, Colombo, Sri Lanka.

Perera, P. A. C. T., Sundarabarathy, T. V., Sivananthawerl, T., Kodithuwakku, S. P., \& Edirisinghe, U. (2016). Arsenic and Cadmium Contamination in Water, Sediments and Fish is a Consequence of Paddy Cultivation: Evidence of River Pollution in Sri Lanka. Achievements in the Life Sciences, 10, 144-160. https://doi.org/10.1016/j.als.2016.11.002

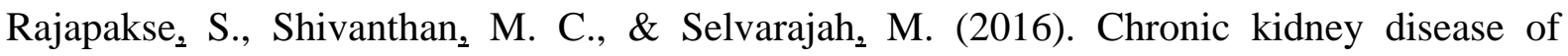
unknown etiology in Sri Lanka. International journal of occupational environmental health, 
259-264. https://doi.org/10.1080/10773525.2016.1203097

Sanjeevani, U. K. P. S., Indraratne, S. P., Weerasooriya, R., Vitharana, U. W. A., \& Kumaragamage, D. (2017). Identifying the Sources and Contamination Status of Potentially Toxic Trace Elements in Agricultural Soils. Communications in Soil science and Plant analysis. https://doi.org/10.1080/00103624.2017.1299168

Sakthivadivel, R., Fernando, N., \& Brewer, J. D. (1997). Rehabilitation planning for small tanks in cascades: A methodology based on rapid assessment. Research Report 13. International Irrigation Management Institute. Colombo, Sri Lanka.

Santschi, P. H., Lenhart, J. J., \& Honeyman, B. D. (1997). Heterogeneous processes affecting trace contaminant distribution in estuaries: the role of natural organic matter. Marine Chemistry, 58, 99-125. https://doi.org/10.1016/S0304-4203(97)00029-7

Schoumans, O. F., Chardon, W. J., Bechmann, M. E., Gascuel-Odoux, C., Hofman, G., Kronvang, B., Rubæk, G. H., Ulén, B., \& Dorioz J.M. (2014). Mitigation options to reduce phosphorus losses from the agricultural sector and improve surface water quality: A review. Science of the total Environment, 468-469: 1255-1266.

https://doi.org/10.1016/j.scitotenv.2013.08.061

Selvarajah, A., \& Thiruchelvam, S. (2007). Factors affecting pesticide use by farmers in Vavuniya District in Sri Lanka. Tropical Agricultural Research, 19, 380-388.

Shihana, F., Jayasekera, J. M. K. B., Dissananyake, D. M., Ratnayake, P., Wickramasinghe, W., \& Radella, Y. A. (2012). The short-term effect of cyanobacterialtoxin extracts on mice kidney in Ileperuma OA, Priyantha N, Navaratne A, Yatigammana SK and Weragoda SK (Eds.) Symposium Proceedings, International Symposium on Water Quality and Human Health: Challenges Ahead, 22-23 March, PGIS, Peradeniya, Sri Lanka.

Siriweera, W. I. (2001). Historical perspectives on small tanks and food security. In Gunasena H PM Ed Food security and small tank systems in Sri Lanka: Proceedings of the workshop organized by the Working Committee on Agricultural Science and Forestry, 9 September 2000. Colombo, Sri Lanka: National Science Foundation (NSF) pp. 7-12.

Soderland, P., Lovekar, S., Weiner, D. E., Brooks, D. R., \& Kaufman, J. S. (2010). Chronic Kidney Disease Associated with Environmental Toxins and Exposures. Advances in Chronic Kidney Disease, 17, 254-264. https://doi.org/10.1053/j.ackd.2010.03.011

Somapala, H. (2001). Small tank system for continued food production with reference to north central and north-western provinces in Gunasena, H P (Ed.) Food security and small tank systems in Sri Lanka: proceedings of the workshop organized by the Working Committee on Agricultural Science and Forestry, 9 September 2000. Colombo, Sri Lanka: National Science Foundation (NFS) pp. 123-129.

Somasiri, S. (2001). Strategies for optimizing food security under small tank system in relation to the high variability of the resource base in Gunasena H PM (Ed.) Food security and small tank systems in Sri Lanka: proceedings of the workshop organized by the Working 


\section{Macrothink}

Environmental Management and Sustainable Development

ISSN 2164-7682

2018, Vol. 7, No. 3

Committee on Agricultural Science and Forestry, 9 September 2000. Colombo, Sri Lanka: National Science Foundation (NSF) pp. 48-63.

Tangahu, B. V., Abdullah, S. R. S., Basri, H., Idris, M., Anuar, N., \& Mukhlisin, M. (2011). A Review on Heavy Metals (As, $\mathrm{Pb}$, and $\mathrm{Hg}$ ) uptake by plants through Phytoremediation. International Journal of Chemical Engineering. http://dx.doi.org/10.1155/2011/939161

Tennakoon, M. U. A. (2015a). Tank terminology, retrieved from http://www.sapsri.lk/tank-terminology/

Tennakoon, M. U. A. (2015b). Traditional Dry Zone Irrigation - Ecosystematic Concepts Revisited and Re conceptualized, South Asia partnership Sri Lanka, Retrieved from http://www.sapsri.lk/traditional-dry-zone-irrigation-ecosystematic-concepts-revisited-and-rec onceptualized/

Wanigasuriya, K. (2014). Update on uncertain etiology of chronic kidney disease in Sri Lanka's north-central dry zone. MEDICC Review, 16, 61-65.

Wanigasuriya, K. (2012). Aetiological factors of Chronic Kidney Disease in the North Central Province of Sri Lanka: A review of evidence to-date. Journal of the college of community physicians of Sri Lanka. Retrieved from http://dx.doi.org/10.4038/jccpsl.v17i1.4931

Wimalawansa, S. J. (2014). Escalating chronic kidney diseases of multifactorial origin in Sri Lanka: causes, solutions, and recommendations. Environmental Health Preventive Medicine, 19, 375-94. https://doi.org/10.1007/s12199-014-0395-5

Wijesekara, R. S. (2016). Present status of groundwater quality and quantity related issues and need for a groundwater monitoring system for Sri Lanka Pathmarajah $S$ (Ed.) Groundwater availability and use in the dry zone of Sri Lanka. Cap-Net Lanka, PGIA, Peradeniya, Sri Lanka 161

Wijesundara, W. M. G. D., Nandasena, K. A., \& Jayakody, A. N. (2014). Hydro-chemical status of the Mahakanumulla cascade in the dry zone of Sri Lanka. Journal of Soil Science Society of Sri Lanka, 24, 15-20.

\section{Copyright Disclaimer}

Copyright for this article is retained by the author(s), with first publication rights granted to the journal.

This is an open-access article distributed under the terms and conditions of the Creative Commons Attribution license (http://creativecommons.org/licenses/by/3.0/). 